\title{
Rhodococcus percolatus sp. nov., a Bacterium Degrading 2,4,6-Trichlorophenol
}

\author{
M. BRIGLIA, ${ }^{1,2 *}$ F. A. RAINEY, ${ }^{3}$ E. STACKEBRANDT, ${ }^{3}$ G. SCHRAA, ${ }^{1}$ \\ AND M. S. SALKINOJA-SALONEN ${ }^{2}$ \\ Department of Microbiology, Wageningen Agricultural University, Wageningen, The Netherlands ${ }^{1}$; \\ Department of Applied Chemistry and Microbiology, Viikki, University of Helsinki, \\ Helsinki, Finland ${ }^{2}$; and Deutsche Sammlung von Mikroorganismen und \\ Zellkulturen $G m b H$, Braunschweig, Germany ${ }^{3}$
}

\begin{abstract}
A bacterial strain that was able to mineralize 2,4,6-trichlorophenol was isolated from a chlorophenol-fed percolator and was identified as a member of the genus Rhodococcus on the basis of chemotaxonomic characteristics and 16S RNA phylogenetic inference data. This organism (strain MBS1 $^{T}[\mathrm{~T}=$ type strain]) exhibited a typical irregular rod-coccus cycle, and the cells had fimbria-like structures on their surfaces. The diagnostic cell wall amino acid was meso-diaminopimelic acid, and the sugars were arabinose and galactose; the mycolic acids contained 46 to 54 carbon atoms. The main menaquinone was $M K-8\left(\mathrm{H}_{2}\right)$, and $M K-9\left(\mathrm{H}_{2}\right)$ was a minor component. The cellular phospholipids were phosphatidylethanolamine, phosphatidylinositol, phosphatidylinositolmannoside, phosphatidylglycerol, and diphosphatidylglycerol. Tuberculostearic acid was present. The whole-cell fatty acids were straight-chain acids with 14 to $18 \mathrm{C}$ atoms. The $\mathrm{G}+\mathrm{C}$ content of the DNA was $67.4 \mathrm{~mol} \%$. This organism grew on sucrose, pyruvate, and 2,4,6-trichlorophenol, and it oxidized a large number of carbon compounds, including catechol, 3-hydroxyphenylacetic acid, and phenol. It also exhibited $\beta$-galactosidase, urease, and 2-acetyl-lactate decarboxylase activities. On a phylogenetic tree that was based on $16 \mathrm{~S}$ ribosomal DNA gene sequences strain $\mathrm{MBS1}^{\mathrm{T}}$ was found among the rhodococci on an independent branch. On the basis of the chemotaxonomic and phenotypic characteristics of strain $\mathrm{MBS1}^{\mathrm{T}}$ and its phylogenetic position we suggest that this bacterium should be placed in a new species, Rhodococcus percolatus; the specific epithet was chosen because the organism was isolated by using an enriched percolator. The type strain is strain MBS1.
\end{abstract}

The members of the order Actinomycetales are important microorganisms that have potential for bioremediation since they degrade both halogenated and nonhalogenated aromatic compounds of environmental concern (44). Some of these organisms, the rhodococci, are widely distributed in soil and sludge and have been shown to attack various xenobiotic compounds $(16,22,33)$. The metabolic versatility of rhodococci has been described previously $(9,42)$.

The order Actinomycetales encompasses a wide range of bacteria that have remarkably different morphological, phenotypic, and chemotaxonomic characteristics (19). Classification of an actinomycete at the genus and species levels can be achieved by determining diagnostic taxonomic characteristics, such as cell amino acid, sugar, respiratory quinone, mycolic acid, fatty acid, and $G+C$ contents. The results of cell wall analyses (sugar and diamino acid analyses) and mycolic acid analyses can be used to distinguish members of the genera Corynebacterium, Gordona, Mycobacterium, Nocardia, Rhodococcus, and Tsukamurella from other actinomycetes (19). Members of these genera have cell walls that contain mesodiaminopimelic acid, arabinose, and galactose (19), as well as mycolic acids. Whole-cell fatty acid patterns and mycolic acid contents can be used to characterize each genus, and these characteristics may differ from one species to another $(12,15)$.

The use of macromolecular sequence comparisons (46) and in particular the use of phylogenetic inferences based on the

\footnotetext{
* Corresponding author. Mailing address: Department of Microbiology, Wageningen Agricultural University, Hesselink van Suchtelenweg, 4, NL-6703 CT Wageningen, The Netherlands. Phone: 31 (0) 317 484099 . Fax: 31 (0) 317483829 . Electronic mail address: maria.briglia @algemeen.micr.wau.nl.
}

gene sequences of rRNAs (10) have contributed significantly to the identification and classification of bacteria. Phylogenetic trees and similarity values provide significant insights into the relationships of bacterial genera and species (10).

In this paper we describe a bacterial strain that is able to grow on 2,4,6-trichlorophenol (2,4,6-TCP) and phenol as sole carbon sources; this strain was isolated from a percolator that was seeded with contaminated sludge and sediment samples and was continuously fed with $2,4,6$-TCP. Taxonomic, morphological, and phenotypic characteristics of this organism are described below, and its phylogenetic position and levels of $16 \mathrm{~S}$ ribosomal DNA (rDNA) sequence similarity with other bacterial species are discussed.

\section{MATERIALS AND METHODS}

Chemicals and media. The medium used as the influent for the percolator system and for the batch culture was minimal salts medium K-N (39). This medium contained (per liter of water) $2 \mathrm{~g}$ of $\mathrm{NH}_{4} \mathrm{Cl}, 2.9 \mathrm{~g}$ of $\mathrm{K}_{2} \mathrm{HPO}_{4}, 2.1 \mathrm{~g}$ of $\mathrm{KH}_{2} \mathrm{PO}_{4}, 0.3 \mathrm{~g}$ of $\mathrm{MgSO}_{4} \cdot 7 \mathrm{H}_{2} \mathrm{O}, 0.1 \mathrm{~g}$ of $\mathrm{NaCl}, 10.0 \mathrm{mg}$ of $\mathrm{CaCl}_{2}$, and $0.1 \mathrm{mg}$ of $\mathrm{FeSO}_{4} ; 5.0 \mathrm{~g}$ of yeast extract per liter was added to the batch culture system and to solidified K-N medium (which contained $13 \mathrm{~g}$ of agar per liter). For percolator enrichment cultures $50 \mathrm{mg}$ of 2,4,6-TCP per liter was added. To isolate single colonies, we used a modified Czapck Dox (mCD) (29) medium that contained (per liter of water) $13 \mathrm{~g}$ of agar, $10 \mathrm{~g}$ of sucrose, $3 \mathrm{~g}$ of $\mathrm{NaNO}_{3}, 1 \mathrm{~g}$ of $\mathrm{K}_{2} \mathrm{HPO}_{4}, 0.5 \mathrm{~g}$ of $\mathrm{MgSO}_{4} \cdot 7 \mathrm{H}_{2} \mathrm{O}, 0.5 \mathrm{~g}$ of $\mathrm{KNO}_{3}$, and $0.001 \mathrm{~g}$ of $\mathrm{FeSO}_{4} \cdot 7 \mathrm{H}_{2} \mathrm{O}$; the $\mathrm{pH}$ of this medium was $7.3 \pm 0.2$. We also used a modified Waksman medium supplemented with antibiotics (2) $(\mathrm{pH} 7.2)$.

Isolation procedure. We used a 1 -liter aerobic semicontinuous percolator system with a down-flow mode to isolate 2,4,6-TCP-degrading strain MBS1 ${ }^{\mathrm{T}}$ (T $=$ type strain). Aerobic and anaerobic sludge samples were used to inoculate the percolator. The anaerobic inocula were obtained from a bioreactor treating pulp bleaching effluents (17) and from a municipal sewage treatment plant in $\mathrm{Hel}$ sinki, Finland (Kyläsaari). The aerobic inocula were obtained from wastewater treatment plants at pulpmills in Pietarsaari, Joutseno, and Varkaus, Finland. The sludge samples were supplemented with wood chips, mixed, and then placed in 
the percolator on polyurethane foam containing active carbon. After 2 months, two-thirds of the recycling liquor was replaced with sterile mineral salts medium, and thereafter this procedure was repeated weekly. A carbon source $(2,4,6-\mathrm{TCP})$ was added weekly to a final concentration of $0.05 \mathrm{~g} /$ liter. After 1 year, in order to isolate 2,4,6-TCP-degrading pure cultures, samples ( 1 to $2 \mathrm{~g}$ of biomass) were removed from the percolator and used to inoculate minimal medium K-N (39) supplemented with $2,4,6$-TCP $(0.01$ to $0.05 \mathrm{~g} /$ liter $)$ as a carbon source. Subsamples were removed from the batches containing biomass that repeatedly degraded the 2,4,6-TCP added and were streaked onto mCD agar supplemented with 2,4,6-TCP. Strain MBS1 ${ }^{\mathrm{T}}$ was isolated as a single colony on an agar plate that was positive for $2,4,6$-TCP degradation. This strain was maintained on $\mathrm{mCD}$ agar containing $0.05 \mathrm{~g}$ of $2,4,6-\mathrm{TCP}$ per liter.

Determination of chemotaxonomic characteristics. Unless indicated otherwise, chemotaxonomic characteristics were determined at the Deutsche Sammlung von Mikroorganismen und Zellkulturen. The cell wall amino acid and sugar contents were determined by using previously described protocols (37).

The whole-cell fatty acids were isolated by using the method of Miller and Berger (31) and were analyzed by gas-liquid chromatography with a HewlettPackard model HP5890A instrument. The fatty acids were identified by comparing our results with the fatty acid patterns of other microorganisms by using the Microbial Identification Systems library (MIS MYCO library; Microbial ID, Newark, Del.). The polar lipids were extracted, separated by two-dimensional thin-layer chromatography, and identified by using a previously described procedure (32)

Isoprenoid quinones were extracted and purified as described by Minnikin et al. (32) and were identified by high-performance liquid chromatography (HPLC) (26).

Trimethylsilylated derivatives of mycolic acids were analyzed by high-temperature gas chromatography and coupled gas chromatography-mass spectrometry.

To determine the $\mathrm{G}+\mathrm{C}$ content. DNA was isolated and purified as described by Cashion et al. (4). After the DNA was degraded (40), it was analyzed by HPLC (30)

Determination of phenotypic characteristics. The ability of strain $\mathrm{MBS1}^{\mathrm{T}}$ to utilize a broad range of carbon sources was determined by using the preselected panel of 95 different carbon-containing compounds provided on a BIOLOG Microplate (BIOLOG, Inc., Hayward, Calif.). BIOLOG microplates rely on the redox dye tetrazolium violet to detect respiration (i.e., NADH formation) in the presence of individual carbon sources. This procedure was performed as described by Garland and Mills (11). Purple wells were scored as positive reactions. API ZYM chromogenic enzyme substrate strips (Appareils et Procédés d'Identification, La Balme Les Grottes, Montalieu Vercieu, France) were used to determine the enzymatic activities of strain $\mathrm{MBS}^{\mathrm{T}}{ }^{\mathrm{T}}$. Enzymatic activity scores $(0$ through 5) were recorded by using the color table which was included with the test kit; reactions which gave scores of $2,3,4$, or 5 were considered positive.

The cell suspension used for all tests was prepared by using cells that were freshly grown on $\mathrm{mCD}$ agar; the cells were added to the wells (BIOLOG tests) or the cupules (API ZYM tests) as recommended by the manufacturers.

Electron microscopic analysis. For the transmission electron microscopy analysis samples of washed cells were negatively stained with $0.2 \%$ phosphotungstic acid. To prepare thin sections, washed cells were embedded in $1.33 \%$ (wt/vol) molten ultrapure agarose in deionized water and fixed with $2.5 \%$ (vol/vol) glutaraldehyde in $0.1 \mathrm{M}$ sodium phosphate buffer $(\mathrm{pH} 7.2)$. The specimens were postfixed in buffered $1 \%$ (wt/vol) osmium tetroxide for $3 \mathrm{~h}$ and then dehydrated in a graded ethanol-propylene oxide series. The cells were then embedded in Spurr low-viscosity resin in three steps $(50,90$, and $100 \%$ [vol/vol] Spurr resin in propylene oxide; ca. $3 \mathrm{~h}$ per step). The whole procedure was carried out at $4^{\circ} \mathrm{C}$ The embedded specimens were allowed to harden in a mold at $60^{\circ} \mathrm{C}$ for $30 \mathrm{~min}$ and then at $70^{\circ} \mathrm{C}$ for $24 \mathrm{~h}$. Thin sections were cut by using a diamond knife and an LKB Ultrotome III ultramicrotome (model $8802 \mathrm{~A}$ ) and were stained with $1 \%$ uranyl acetate and then with $2 \%$ lead citrate for $10 \mathrm{~min}$. The resulting grids were examined with a model $\mathrm{CM}_{12}$ transmission electron microscope (Philips, Eindhoven, The Netherlands) at an operating voltage of $60 \mathrm{kV}$.

For the scanning electron microscopy analysis 10 to $50 \mu \mathrm{l}$ of cells that had been washed three times with demineralized water was poured onto a Millipore filter (pore size, $0.45 \mu \mathrm{m}$ ) in a critical point drier and then fixed with $2 \%(\mathrm{vol} / \mathrm{vol}$ ) glutaraldehyde in $0.1 \mathrm{M}$ cacodylate buffer ( $\mathrm{pH} 7.4$ ) overnight. Then the samples were rinsed twice with demineralized water, dehydrated in ethanol as describe above, and critical point dried in $\mathrm{CO}_{2}$. The filters were put on an aluminum stub and coated with gold palladium for $2 \mathrm{~min}$. The resulting specimens were examined with a Philips model $535 \mathrm{M}$ scanning electron microscope.

Isolation of nucleic acids and sequencing methods. Extraction of genomic DNA, amplification of genes encoding the 16S rRNA, and purification of the PCR products were performed as described previously by Rainey et al. (36). A computer analysis of the sequence data was performed by using the program PC/GENE (version 5.01; Genofit, Geneva, Switzerland) and the Genetics Computer Group package (version 6.0) (7).

DNA-DNA hybridization. DNA was isolated by chromatography on hydroxyapatite by using the procedure of Cashion et al. (4). DNA-DNA hybridization was performed as described by De Ley et al. (5) by using the modifications described by Huss et al. (20) and a Gilford model 2600 spectrophotomete equipped with a Gilford model 2527-R thermoprogrammer and plotter. Renaturation rates were computed with the TRANSFER.BAS program (21).
Phylogenetic analysis. The Rhodococcus percolatus MBS1 ${ }^{\mathrm{T}}$ 16S rDNA gene sequence was aligned manually with sequences obtained from the database of Larsen et al. (28). The $R$. percolatus sequence was also compared with the sequences of the actinomycetes that contain mycolic acids. Pairwise evolutionary distances (expressed as estimated numbers of changes per 100 nucleotides) were computed from percentages of similarity by using the correction of Jukes and Cantor (23). Phylogenetic trees were constructed from the distance matrices by using a least-squares algorithm (6) and the neighbor-joining method.

Determination of cell surface hydrophobicity. To determine the cell surface hydrophobicity of strain MBS1 ${ }^{\mathrm{T}}$, the contact angle between a drop of demineralized $\mathrm{H}_{2} \mathrm{O}$ and a bacterial layer on a microfilter was determined in triplicate as described by Van Loosdrecht et al. (43). The cells of strain MBS1 ${ }^{\mathrm{T}}$ used for these measurements were grown to the exponential and late stationary phases, and samples were prepared as described previously by Briglia et al. (3).

Determination of production of biosurfactant. The release of a biosurfactant by strain $\mathrm{MBS1}^{\mathrm{T}}$ cells into the culture supernatant was assayed by using a Wilhelmy plate tensiometer. The surface tension $(\gamma)$ was calculated from the equation $\gamma=9.81 K / 2 L \cdot N / m$, where $K$ was the reading given by the tensiometer during the measurement, $L$ was the length of the platinum plate, and $N / m$ was the force applied. Three batch cultures in $\mathrm{mCD}$ medium containing $1 \mathrm{~g}$ of sucrose per liter as a carbon source and three batch cultures containing $0.1 \mathrm{~g}$ of phenol or 2,4,6-TCP per liter were inoculated with approximately the same number of cells. One whole batch $(40 \mathrm{ml})$ was used for each measurement, and samples were removed after 1,2 , and 3 days of incubation.

Nucleotide sequence accession number. The 16S rDNA gene nucleotide sequence of $R$. percolatus $\mathrm{MBS}^{\mathrm{T}}$ has been deposited in the EMBL data library under accession number X92114.

\section{RESULTS}

Isolation of a bacterium that degrades 2,4,6-TCP. A mixture of inocula obtained from different contaminated sludge and sediment samples was acclimated to 2,4,6-TCP, and samples were removed from the resulting enrichment culture and grown in medium containing 2,4,6-TCP as the sole carbon source. Strain MBS1 ${ }^{\mathrm{T}}$ was the only bacterium that metabolized 2,4,6-TCP; the other bacteria present in the degrading consortium were not able to use 2,4,6-TCP. Agar petri dishes that contained $10 \mathrm{~g}$ of sucrose per liter and $0.05 \mathrm{~g}$ of 2,4,6-TCP per liter and were streaked with samples obtained from the culture described above were predominantly covered by large pink colonies and small transparent colonies. The latter did not grow on 2,4,6-TCP.

Morphology, size, ultrastructure, and characteristics of strain MBS1 $^{\mathrm{T}}$ cells. Strain MBS1 ${ }^{\mathrm{T}}$ formed light pink colonies on mCD agar supplemented with $10 \mathrm{~g}$ of sucrose per liter and was gram positive. The colonies were smooth, opaque, and low convex with slightly irregular edges. A primary mycelium that was on the surface and penetrated into the agar was visible when cultures were examined with a light stereomicroscope. The colonies became dark pink if they were exposed to daylight. The cells formed a primary mycelium that soon fragmented into rod to coccoid elements. When cells were grown in liquid medium containing sucrose as the sole carbon source, they were 2.6 to 8.7 by 0.7 to $1.1 \mu \mathrm{m}$ whether $2,4,6-\mathrm{TCP}$ was present or not (Fig. 1 and 2A). The cell wall appeared to be a homogeneous structure typical of gram-positive bacteria. Long rod-shaped cells that had more than one septum were often found. When cells were grown in $\mathrm{mCD}$ liquid medium containing 2,4,6-TCP or phenol as the sole carbon source, they were 0.7 to 1.8 by 0.4 to $0.7 \mu \mathrm{m}$. Similar cells were also observed in a 1-year-old culture grown by using sucrose as the sole carbon source (Fig. $1 \mathrm{~B}$ and $\mathrm{b}$ ). Figures 1 and 2 illustrate the morphological peculiarities of strain MBS1 ${ }^{\mathrm{T}}$. Typical $\mathrm{V}$ forms that were produced by snapping division were observed after negative staining (Fig. 1A) and in scanning electron micrographs (Fig. 1D) and thin-section micrographs (Fig. 2C). Cell division created blunt ends, as shown by scanning electron microscopy (Fig. 1D) and thin-section transmission electron microscopy (Fig. 2B). In some thin sections, we identified two distinct layers in the cell wall, an outer layer and an inner 

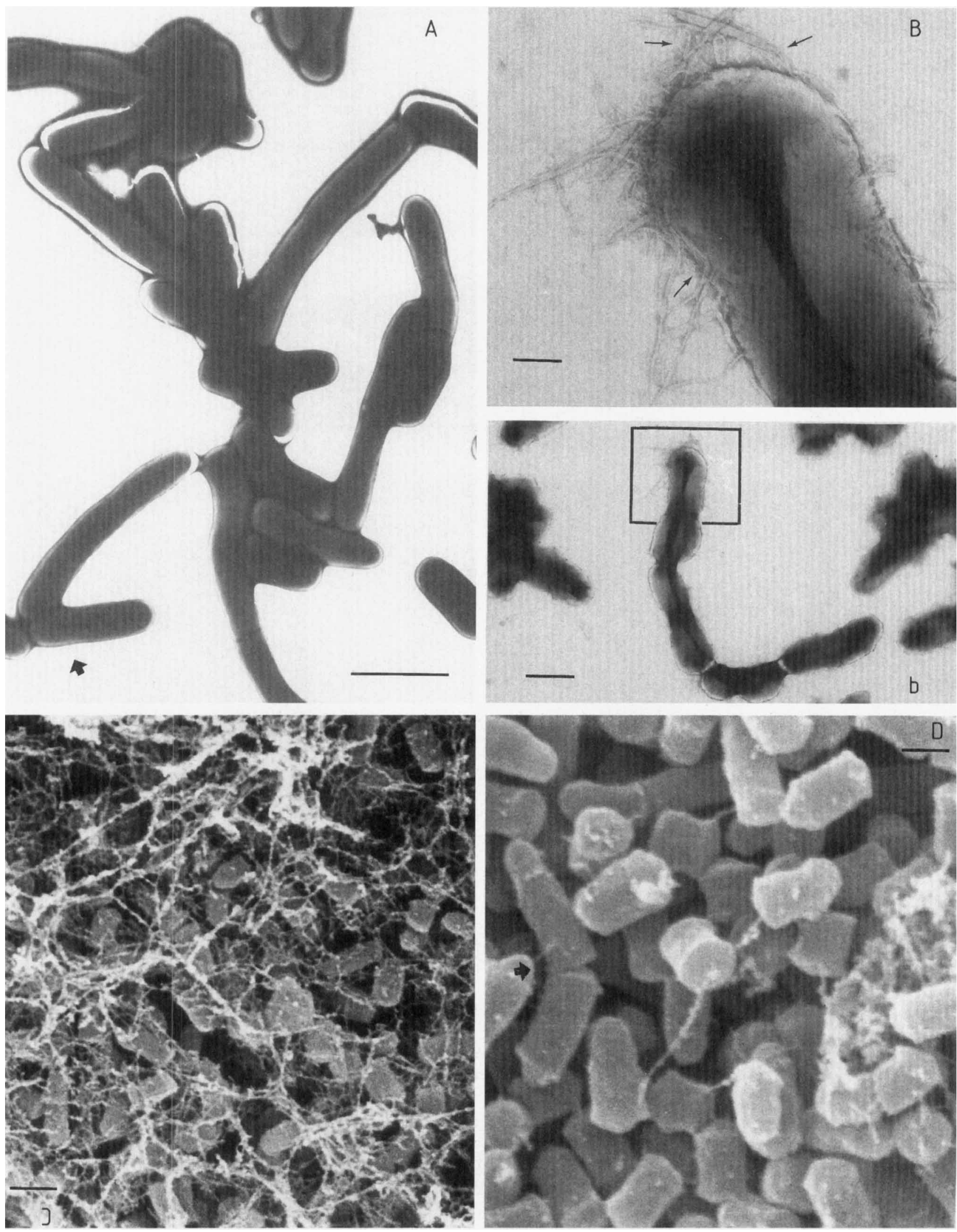

FIG 1. Morphology of strain MBS1 $1^{\mathrm{T}}$ as determined by transmission electron microscopy and scanning electron microscopy. (A, B, and b) Negatively stained transmission electron micrographs. (C and D) Cryofixed scanning electron micrographs. (A) Morphological differentiation and cell size at the early stationary phase. Cells were grown on sucrose as the sole carbon source. Magnification, $\times 7,830$. Bar $=2 \mu \mathrm{m}$. The uniformity of the negative staining and the lack of cell surface details are typical of gram-positive organisms. Typical V forms (arrows) are shown in panels A and D. (B and b) Presence of fimbria-like structures (arrows) on cell surfaces and around 1-year-old cells grown on sucrose as the sole carbon source. The close-up in panel B shows these structures in more detail. (B) Magnification, $\times 43,326$. Bar $=0.2 \mu \mathrm{m}$. (b) Magnification, $\times 7,830$. Bar $=1 \mu \mathrm{m}$. (C) Presence of extracellular material around the cells. Magnification, $\times 4,350$. Bar $=2 \mu \mathrm{m}$. (D) Snapping division (arrow) and the resulting blunt ends of the daughter cells. Extracellular material is also present on the right side. Magnification, $\times 8,700$. Bar $=1 \mu \mathrm{m}$. 

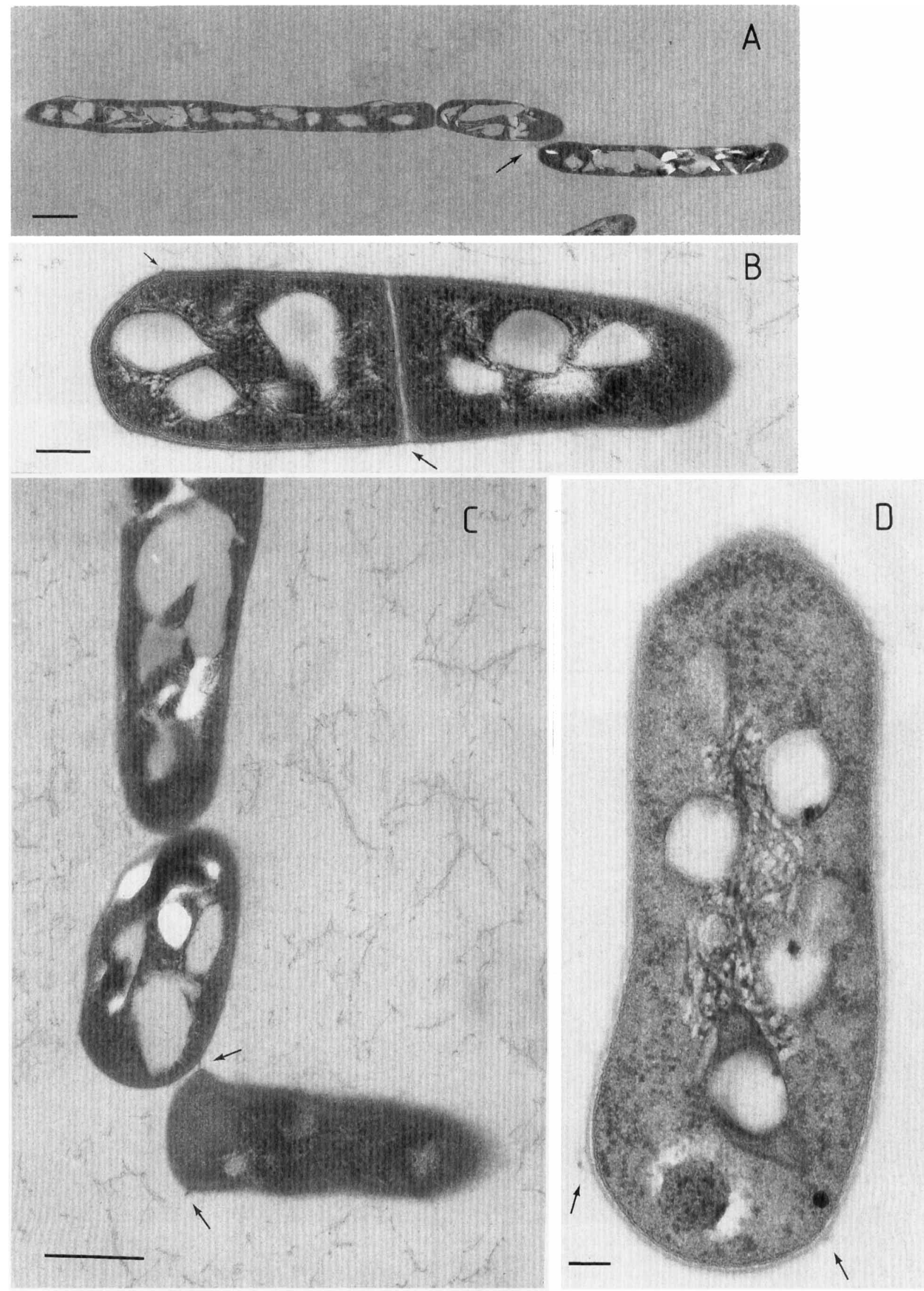

FIG. 2. Electron micrographs of thin sections of young cells of strain MBS1 ${ }^{\mathrm{T}}$. (A) Extracellular material (arrow). Magnification, $\times 8,736$. Bar $=1 \mu \mathrm{m} .(\mathrm{B})$ Cell wall, septum, and granules. Magnification, $\times 47,808$. Bar $=0.2 \mu \mathrm{m}$. (C) Cell wall scars (arrows), which are also visible in panels B and D (arrows). Magnification, $\times 37,440$. Bar $=0.5 \mu \mathrm{m} .(\mathrm{D})$ Granules. Magnification, $\times 77,760$. Bar $=0.1 \mu \mathrm{m}$. 
TABLE 1. Use of different substrates as sole carbon sources for respiration (formation of NADH) by $R$. percolatus MBS1 $^{\mathrm{T}}$

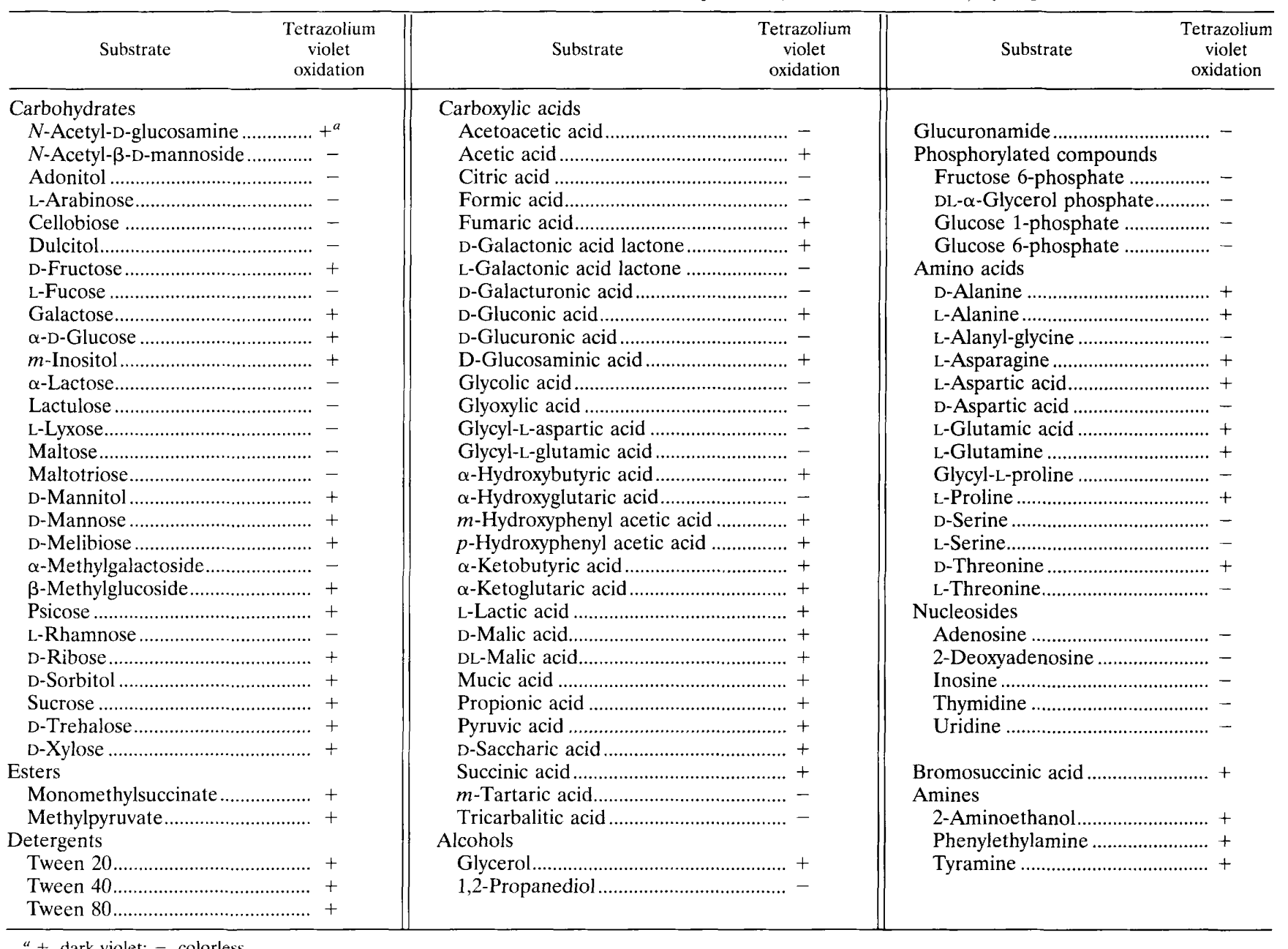

$a+$, dark violet; - , colorless.

invaginating layer, especially in regions where septa were formed (Fig. 2B). Rupturing of the outer layer was observed in the walls of daughter cells that were recently separated or still attached on one side in the typical V forms (Fig. 2C). Extracellular material extruding from strain $\mathrm{MBS1}^{\mathrm{T}}$ cells was observed in scanning electron micrographs (Fig. 1C and D), and this material attached cells to one another, as shown by thinsection micrographs (Fig. 2A). Perhaps the most interesting feature of strain $\mathrm{MBS}^{\mathrm{T}}{ }^{\mathrm{T}}$ cells was the presence of fimbria-like structures that were visible on the surfaces (Fig. 1B and b) of cells negatively stained with phosphotungstic acid. These structures seemed to contain repeating subunits, as shown by transmission electron microscopy (Fig. 1B). Storage granules that looked like poly- $\beta$-hydroxybutyrate droplets were often observed (Fig. 2). The granules were larger and there were more granules in young cells than in old or stressed cells.

The surfaces of strain $\mathrm{MBS}^{\mathrm{T}}$ cells were hydrophobic, as indicated by the contact angles with drops of water $\left(57^{\circ}\right.$ and $59^{\circ}$ ); the values which we obtained were independent of the growth phase or age of the culture.

Physiological properties and nutritional requirements. Strain $\mathrm{MBS1}^{\mathrm{T}}$ grew optimally at 27 to $30^{\circ} \mathrm{C}$ in mCD medium containing sucrose with or without $2,4,6-\mathrm{TCP}$, at $\mathrm{pH} 7$ to 7.5 , and in the dark, and growth was inhibited at $\mathrm{pH}$ values below 6.5 and above 8 . Strain $\mathrm{MBS}^{\mathrm{T}}$ grew in $\mathrm{MCD}$ medium contain- ing pyruvate, yeast extract, phenol, and 2,4,6-TCP as sole carbon sources. It also grew on other xenobiotic compounds, including 2-monochlorophenol, 4-monochlorophenol, 6-monochlorophenol, 2,3-dichlorophenol, 3,4-dichlorophenol, 2,4,5trichlorophenol, 2,3,6-trichlorophenol, and toluene (2a). Positive reactions were obtained with 51 of the 95 compounds tested for NADH generation (11) (Table 1). The $\beta$-galactosidase, urease, and 2-acetyl-lactate decarboxylase activities of strain MBS1 ${ }^{\mathrm{T}}$ were determined by the API ZYM chromogenic test.

Production of biosurfactant. Strain $\mathrm{MBS}^{\mathrm{T}}$ was tested for production of a surfactant in mCD medium containing sucrose, pyruvate, phenol, or 2,4,6-TCP as the carbon source by measuring the surface tension of the culture supernatant. The surface tensions of supernatants from cultures incubated for 2 and 3 days were lower than the surface tensions of supernatants after 1 day of incubation. The surface tension of a 7-dayold culture supernatant was $0.054 \pm 0.0055 \mathrm{~N} / \mathrm{m}$, a value which was significantly lower than the surface tension of water $(0.072$ $\pm 0.0025 \mathrm{~N} / \mathrm{m})$. Decreases in surface tension were observed with all four carbon sources tested.

Chemotaxonomic characterization. The cell wall of strain MBS1 $^{\mathrm{T}}$ contained meso-diaminopimelic acid as the only diamino acid and arabinose and galactose as the major sugars, indicating that the cell wall type is type IV, which is typical of 
TABLE 2. Fatty acid profile of $R$. percolatus $\mathrm{MBS}^{\mathrm{T}}$

\begin{tabular}{lrr}
\hline \multirow{2}{*}{ Fatty acid $^{a}$} & \multicolumn{2}{c}{$\%$ in strain MBS1 } \\
\cline { 2 - 3 } & Mean $^{b}$ & SD \\
\hline $14: 0$ & 2.8 & 0.1 \\
$15: 1$ B & 0.9 & 0.1 \\
$15: 0$ & 11.7 & 0.5 \\
$16: 1$ cis 9 & 8.8 & 0.3 \\
$16: 0$ & 24.0 & 1.1 \\
$17: 1$ B & 19.1 & 1.5 \\
17:0 & 9.8 & 1.1 \\
18:1 iso F & 1.0 & 0.5 \\
18:1 cis 9 & 10.9 & 1.0 \\
TBSA 10Me 18:0 & 0.9 & 0.5 \\
Other & $<3$ & \\
\hline
\end{tabular}

${ }^{a}$ Abbreviations: $14: 0$, tetradecanoate; $15: 0$, pentadecanoate; $15: 1 \mathrm{~B}$, branched pentadecenoate; $16: 0$, hexadecanoate; $16: 1$ cis 9 , cis-9-hexadecenoate; 17:0, heptadecanoate; $17: 1 \mathrm{~B}$, branched heptadecenoate; $18: 1$ iso $\mathrm{F}$, iso-F-octadecenoate; 18:1 cis 9 , cis-9-octadecenoate; TBSA, tuberculostearic acid.

${ }^{b}$ Means from three independent analyses.

nocardioform actinomycetes. The $\mathrm{G}+\mathrm{C}$ content of the DNA of strain $\mathrm{MBS}^{\mathrm{T}}$ was $67.4 \mathrm{~mol} \%$. The major menaquinone $(94 \%)$ detected in strain $\mathrm{MBS}^{\mathrm{T}}$ was $\mathrm{MK}-8\left(\mathrm{H}_{2}\right)$; a small amount $(6 \%)$ of MK-9 $\left(\mathrm{H}_{2}\right)$ was also present. The length of the carbon chain of the mycolic acid as determined by pyrolysis gas chromatography was 46 to 54 atoms. Tuberculostearic acid was present $(0.9 \%)$. The cellular phospholipids were phosphatidylethanolamine, phosphatidylinositol, phosphatidylinositolmannoside, phosphatidylglycerol, and diphosphatidylglycerol. The whole-cell saturated fatty acids included hexadecanoic acid $(24 \%)$, pentadecanoic acid (11 to $12 \%$ ), heptadecanoic acid (9 to $10 \%)$, octadecanoic acid (1 to $2 \%$ ), and tetradecanoic acid ( 2 to $3 \%$ ). The unsaturated fatty acids were cisoctadec-9-enoic acid (10 to $11 \%$ ) and cis-hexadec-9-enoic acid (8 to $9 \%$ ) (Table 2). Thus, the cellular fatty acid pattern of strain $\mathrm{MBS1}^{\mathrm{T}}$ differed from the patterns of the previously described rhodococci $(1,12,14,19,24,38,41)$ included in the MIS and Myco.M15 libraries.

$16 S$ rDNA gene sequence and phylogenetic inference. The $16 \mathrm{~S}$ rDNA sequence of strain MBS1 $^{\mathrm{T}}$ was determined and deposited in the EMBL sequence databank. This nucleotide sequence was compared with the previously described $16 S$
rDNA sequences of actinomycetes which contain mycolic acids (members of the genera Gordona, Mycobacterium, Nocardia, Tsukamurella [data not shown], and Rhodococcus), and a similarity matrix was constructed (Table 3 ). A high level of similarity $(99.3 \%)$ was found between strain MBS- $1^{\mathrm{T}}$ and Rhodococcus opacus.

We constructed a phylogenetic tree by using a least-squares algorithm and the neighbor-joining method. Strain $\mathrm{MBS}^{\mathrm{T}}$ clustered within the confines of the genus Rhodococcus on an individual branch of this tree and shared a bifurcation with $R$. opacus (Fig. 3).

In addition, we performed a DNA-DNA hybridization analysis with strain $\mathrm{MBS}^{\mathrm{T}}$ and $R$. opacus and obtained a homology value of $71 \%$, which indicated that these two organisms are different.

\section{DISCUSSION}

The results of our morphological, physiological, and chemotaxonomic analyses and our phylogenetic inferences based on 16S rRNA data indicate that strain $\mathrm{MBS1}^{\mathrm{T}}$ belongs to the genus Rhodococcus. In fact, strain $\mathrm{MBS1}^{\mathrm{T}}$ cells produce branched hyphal structures that fragment into irregular rodshaped and coccoid units which are typical of rhodococci (1315). To our knowledge, strain MBS1 $1^{\mathrm{T}}$ is the first described rhodococcus whose cell walls are composed of two morphologically distinct layers. Similar cell walls have been found in other actinomycetes belonging to the coryneform group. Farshtchi and McClung (8) observed similar structures in thin sections of Nocardia asteroides 176, and Krulwich and Pate (27) observed similar structures in Arthrobacter crystallopoietes ATCC 15481. Krulwich and Pate (27) demonstrated that the inner layer participated in septum formation, while the outer layer remained intact until cross wall formation was complete. Our micrographs showed that strain $\mathrm{MBS1}^{\mathrm{T}}$ exhibited a mode of septation similar to the mode of septation which has been described for coryneform genera $(8,27)$. This finding may have taxonomic relevance. The fimbria-like structures found on the surfaces of strain $\mathrm{MBS}^{\mathrm{T}}$ cells seem to be unique among the rhodococci that have been described so far. Similar structures were found on the surfaces of Corynebacterium renale cells by Yanagawa et al. (45). Another example of a microorganism other than a gram-negative bacterium that has such structures was described by Poon and Day (34), who found fimbriae on

TABLE 3. Levels of $16 \mathrm{~S}$ rDNA similarity between $R$. percolatus and the type strains of all previously validly described Rhodococcus species

\begin{tabular}{|c|c|c|c|c|c|c|c|c|c|c|c|}
\hline \multirow[b]{2}{*}{ Species } & \multicolumn{11}{|c|}{$\% 16 \mathrm{~S}$ rDNA similarity to: } \\
\hline & 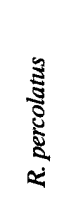 & 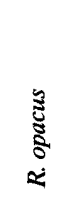 & 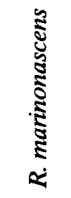 & 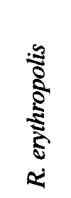 & 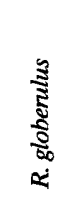 & 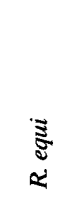 & 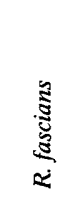 & 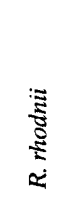 & 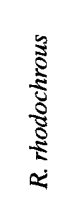 & 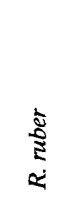 & $\begin{array}{l}\mathbf{\Sigma} \\
\frac{5}{2} \\
2 \\
\alpha\end{array}$ \\
\hline R. opacus & 99.3 & & & & & & & & & & \\
\hline R. marinonascens & 98.3 & 98.5 & & & & & & & & & \\
\hline R. erythropolis & 97.5 & 97.5 & 98.3 & & & & & & & & \\
\hline R. globerulus & 97.5 & 97.5 & 97.6 & 98.3 & & & & & & & \\
\hline R. equi & 97.3 & 97.7 & 97.0 & 96.4 & 96.7 & & & & & & \\
\hline R. fascians & 96.6 & 96.6 & 96.8 & 97.2 & 97.0 & 96.1 & & & & & \\
\hline R. rhodnii & 96.1 & 96.6 & 96.4 & 96.5 & 96.4 & 96.3 & 96.1 & & & & \\
\hline R. rhodochrous & 95.3 & 95.7 & 95.7 & 95.7 & 95.2 & 96.4 & 95.0 & 96.3 & & & \\
\hline R. ruber & 95.2 & 95.7 & 95.5 & 95.5 & 95.0 & 95.9 & 94.8 & 96.8 & 97.6 & & \\
\hline R. zopfii & 96.1 & 96.5 & 96.3 & 96.0 & 95.6 & 96.5 & 95.1 & 97.0 & 97.5 & 97.6 & \\
\hline R. coprophilus & 96.1 & 96.3 & 96.9 & 96.6 & 95.8 & 95.9 & 95.6 & 96.1 & 97.7 & 97.2 & 97.7 \\
\hline
\end{tabular}




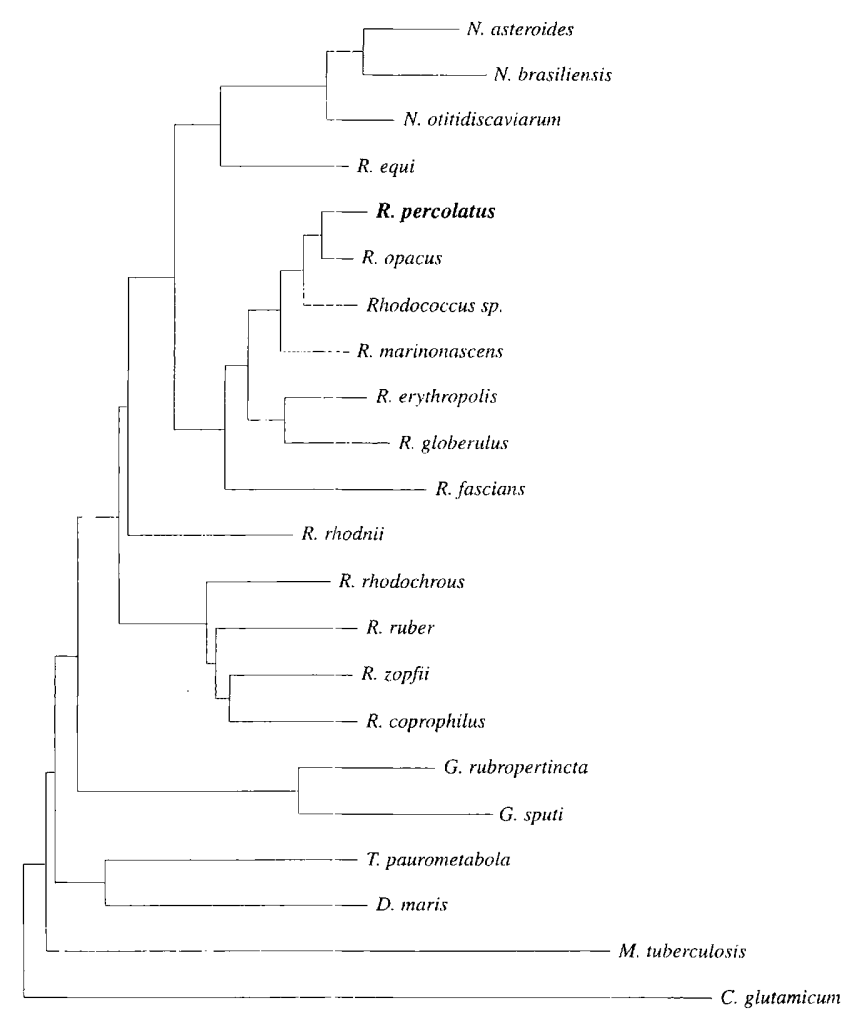

$5 \%$

FIG. 3. Phylogenetic dendrogram based on the results of a 16S rDNA sequence comparison. All of the sequences used were the sequences of type strains. The Rhodococcus sp. strain used was strain DSM 43943. Bar $=5$ nucleotide substitutions per 100 nucleotides. N., Nocardia; R., Rhodococcus; G., Gordona; T., Tsukamurella; D., Deleya; M., Mycobacterium; C., Corynebacterium.

the cell walls of the anther smut species Ustilago violacea. These authors reported that fimbriae were abundant on logphase cells but not on stationary-phase cells and that they were not stained by phosphotungstic acid or ruthenium red $(34,35)$.

The presence of tuberculostearic acid and the high $\mathrm{G}+\mathrm{C}$ content of strain $\mathrm{MBS1}^{\mathrm{T}}$ clearly distinguish this organism from members of the genus Corynebacterium. The menaquinone type $\left[\mathrm{MK}-8\left(\mathrm{H}_{2}\right)\right]$ and the length of the mycolic acids of strain MBS1 $^{\mathrm{T}}$ place this organism in the genus Rhodococcus and distinguish it from members of the genera Gordona, Mycobacterium, Nocardia, and Tsukamurella, which contain menaquinone MK-9 $\left(\mathrm{H}_{2}\right)$ and mycolic acids with multiple chains or longer chains (12-14).

Several phenotypic characteristics of strain $\mathrm{MBS1}^{\mathrm{T}}$, such as the ability to oxidize a broad range of carbon compounds (1, $12,14,18,19,42)$, as well as the cellular fatty acid pattern (1, $12,19,38)$, differentiate this strain from other Rhodococcus species. Strain $\mathrm{MBS1}^{\mathrm{T}}$ also differs from the closely related organism $R$. opacus (25) in its utilization of five basic substrates. Strain $\mathrm{MBS}^{\mathrm{T}}{ }^{\mathrm{T}}$ uses proline as an energy source, while $R$. opacus does not; and strain $\mathrm{MBS}^{\mathrm{T}}$ does not use citrate, cellobiose, lactose, and maltose, while $R$. opacus does utilize these substrates. Moreover, strain $\mathrm{MBS}^{\mathrm{T}}$ can grow on xenobiotic compounds, such as 2,3-dichlorophenol, 3,4-dichlorophenol, 2,4,5-trichlorophenol, 2,3,6-trichlorophenol, and toluene (2a), and on 2,4,6-TCP, while $R$. opacus GM 14 cannot (45a). In addition, strain MBS1 ${ }^{\mathrm{T}}$ does not contain cis-7-hexadecenoate, cis-8-heptadecenoate, and octadecanoate, while $R$. opacus does, and tuberculostearic acid is present in lower amounts in strain $\mathrm{MBS}^{\mathrm{T}}$ than in $R$. opacus. Strain MBS1 $1^{\mathrm{T}}$ also differs from the toxicant-degrading organism Rhodococcus zopfii, which does not contain pentadecanoate but does contain high levels of hexadecanoate and tuberculostearic acid (38). The chain lengths of the mycolic acids of strain MBS1 $1^{\mathrm{T}}$ (46 to 54 carbon atoms) also differ from the chain lengths of the mycolic acids of other Rhodococcus strains (1, 18, 38, 41).

Phylogenetic analysis based on rDNA sequences is currently one of the most powerful methods for estimating relationships of microorganisms (10) since the results of such an analysis usually exhibit an excellent correlation with chemotaxonomic and physiological characteristics. In fact, a comparison of the $16 \mathrm{~S}$ rDNA sequence of strain $\mathrm{MBS1}^{\mathrm{T}}$ with the sequences of other prokaryotes placed strain $\mathrm{MBS}^{\mathrm{T}}$ in the gram-positive, high-G + C-content group of the Bacteria, most closely related to the Rhodococcus species whose 16S rDNA sequences are known (Table 3 and Fig. 3). Thus, the results obtained in the phylogenetic inference analysis are consistent with the results obtained in the chemotaxonomic analyses; both types of results indicated that strain MBS1 ${ }^{\mathrm{T}}$ belongs to the genus Rhodococcus. Furthermore, chemotaxonomic and metabolic data confirmed that strain $\mathrm{MBS}^{\mathrm{T}}$ is different from the Rhodococcus species described previously $(1,14,18,19,25,38,41)$.

On the basis of the results described above it appears that strain $M B S 1^{\mathrm{T}}$ represents a new Rhodococcus species, for which we propose the name Rhodococcus percolatus.

Description of Rhodococcus percolatus sp. nov. Rhodococcus percolatus (per.co.la'tus. L. n. percolatus, referring to the percolator system used for isolation). Cells are gram positive. Grows on sucrose, pyruvate, phenol, and 2,4,6-TCP as sole carbon and energy sources. 2-Acetyl-lactate decarboxylase, $\beta$-galactosidase, and urease positive. Forms a primary mycelium that fragments into rod and coccus elements. On mCD agar containing sucrose colonies are light pink. Visible growth resulting from dilute inocula in $\mathrm{mCD}$ medium supplemented with $1 \%$ sucrose, $1 \%$ pyruvate, or $1 \%$ glucose requires 1 to 2 days at $28^{\circ} \mathrm{C}$. The cell wall contains meso-diaminopimelic acid, arabinose, and galactose.

The mycolic acids contain 46 to 54 carbon atoms. The $\mathrm{G}+$ $\mathrm{C}$ content is $67.4 \mathrm{~mol} \%$. The main menaquinone is $\mathrm{MK}-8\left(\mathrm{H}_{2}\right)$. The cellular phospholipids are phosphatidylethanolamine, phosphatidylinositol, phosphatidylinositolmannoside, phosphatidylglycerol, and diphosphatidylglycerol. The type strain, strain MBS1, was isolated from a 2,4,6-TCP-containing enrichment culture in a percolator inoculated with contaminated sludge and sediment samples at the University of Helsinki, Helsinki, Finland.

Strain MBS1 ${ }^{\mathbf{T}}$ has been deposited in the Culture Collection of the Department of Microbiology at Wageningen Agricultural University, Wageningen, The Netherlands, as strain LMAU.R292 and in the University of Helsinki HAMBI Collection as strain HAMBI1752.

\section{ACKNOWLEDGMENTS}

We thank Riitta Boeck, Department of Applied Chemistry and Microbiology, University of Helsinki, for performing the fatty acid analyses; E.-L. Nurmiaho-Lassila, Department of General Microbiology, University of Helsinki, for providing comments on the electron micrographs; E. van Balen, IPO-DLO, Wageningen, The Netherlands, for providing excellent thin sections; A. Klerkx for performing the scanning electron microscopic analysis; C. R. Koedam for printing the electron micrographs; J. D. Janse, Plant Protection Service, DLO, Wageningen, The Netherlands, for useful discussions; R. M. Kroppenstedt, Deutsche Sammlung von Mikroorganismen und Zellkulturen $\mathrm{GmbH}$, Braunschweig, Germany, for performing some of the chemotaxonomic analyses; W. J. Middelhoven, Department of Microbiology, 
Wageningen Agricultural University, Wageningen, The Netherlands, for providing helpful suggestions and scientific advice and for critically reading the manuscript; and $\mathrm{N}$. Slotboom for providing the artwork.

This work was supported by a grant from the Finnish Maj and Tor Nessling Foundation (to M.B. and M.S.-S.) and by EU contract EV5VCT 93-0250 (to M.S.-S.).

\section{REFERENCES}

1. Asturias, J. A., E. Moore, M. H. Yakimov, S. Klatte, and K.-N. Timmis. 1994. Reclassification of the polychlorinated biphenyl-degraders Acinetobacter $\mathrm{sp}$. strain P6 and Conynebacterium sp. strain MB1 as Rhodococcus globerulus. Syst. Appl. Microbiol. 17:226-231.

2. Briglia, M. 1986. Impiego di antibiotici per l'isolamento e la conta degli attinomiceti dal suolo. Agricoltura Italiana Fascolo 1/2:17-28.

2a.Briglia, M. Unpublished data.

3. Briglia, M., P. J. M. Middeldorp, and M. S. Salkinoja-Salonen. 1994. Mineralization performance of Rhodococcus chlorophenolicus strain PCP-1 in contaminated soil simulating on site conditions. Soil Biol. Biochem. 26:377385 .

4. Cashion, P., M. A. Holder-Franklin, J. M. MacCully, and M. Franklin. 1977. A rapid method for the base ratio determination of bacterial DNA. Anal. Biochem. 81:461-466.

5. De Ley, J. H., H. Cattoir, and A. Reynaerts. 1970. The quantitative measurement of DNA hybridization from renaturation rates. Eur. J. Biochem. 12:133-142.

6. De Soete, G. 1983. A least squares algorithm for fitting additive trees to proximity data. Psychometrica 48:621-626.

7. Devereux, J., P. Haeberli, and O. Smithies. 1984. A comprehensive analysis program for the VAX. Nucleic Acids Res. 12:387-395.

8. Farshtchi, D., and N. M. McClung. 1967. Fine structure of Nocardia asteroides grown in a chemically defined medium. J. Bacteriol. 94:255-257.

9. Finnerty, W. R. 1992. The biology and genetics of the genus Rhodococcus. Annu. Rev. Microbiol. 46:193-218.

10. Fox, G. E., E. Stackebrandt, R. B. Hespell, J. Gibson, J. Maniloff, T. A. Dyer, R. S. Wolfe, R. Gupta, L. Bonen, B. J. Lewis, D. A. Stahl, K. R. Luehrson, K. N. Chen, and C. R. Woese. 1980. The phylogeny of prokaryotes. Science 209:457-463.

11. Garland, J. L., and A. L. Mills. 1991. Classification and characterization of heterotrophic microbial communities on the basis of patterns of communitylevel sole-carbon-source utilization. Appl. Environ. Microbiol. 57:2351-2359.

12. Goodfellow, M. 1984. Reclassification of Connebacterium fascians (Tilford) Dowson in the genus Rhodococcus, as Rhodoccus fascians comb. nov. Syst. Appl. Microbiol. 5:225-229.

13. Goodfellow, M. 1989. Genus Rhodococcus, p. 2362-2371. In S. T. Williams, M. E. Sharpe, and J. G. Holt (ed.), Bergey's manual of systematic bacteriology, vol. 4. The Williams \& Wilkins Co., London.

14. Goodfellow, M. 1991. The family Nocardiaceae, p. 1188-1213. In A. Balows, H. G. Truper, M. Dworkin, W. Harder, and K. H. Schleifer (ed.), The prokaryotes, 2nd ed. Springer-Verlag, New York.

15. Goodfellow, M., and G. Alderson. 1977. The actinomycete-genus Rhodococcus: a home for the "rhodochrous" complex. J. Gen. Microbiol. 100:99-122.

16. Häggblom, M. M., D. Janke, and M. S. Salkinoja-Salonen. 1989. Transformation of chlorinated phenolic compounds in the genus Rhodococcus. Microb. Ecol. 18:305-314.

17. Häggblom, M. M., and M. S. Salkinoja-Salonen. 1991. Biodegradability of chlorinated organic compounds in pulp bleaching effluents. Water Sci. Technol. 24:161-170.

18. Helmeke, E., and H. Weyland. 1984. Rhodococcus marinonascens sp. nov., an actinomycete from the sea. Int. J. Syst. Bacteriol. 34:127-138.

19. Holt, J. G., N. R. Krieg, P. H. A. Sneath, J. T. Staley, and S. T. Williams. 1994. Bergey's manual of determinative bacteriology, 9th ed., p. 625-650. Williams \& Wilkins Co., London.

20. Huss, V. A. R., H. Festl, and K. H. Schleifer. 1983. Studies on the spectrophotometric determination of DNA hybridization from renaturation rates. Syst. Appl. Microbiol. 4:184-192.

21. Jahnke, K.-D. 1992. BASIC computer program for evaluation of spectroscopic DNA renaturation data from GILFORD SYSTEM 2600 spectrophotometer on a PC/XT/AT type personal computer. J. Microbiol. Methods 15:61-73.

22. Jahnke, D., W. Ihn, and D. Tresselt. 1989. Critical steps in degradation of chloroaromatics by rhodococci. IV. Detailed kinetics of substrate removal and product formation by resting pre-adapted cells. J. Basic Microbiol. 29:305-314.

23. Jukes, T. H., and C. R. Cantor. 1969. Evolution of protein molecules, p. 21-132. In H. N. Munro (ed.), Mammalian protein metabolism. Academic Press, New York.

24. Klatte, S., K.-D. Jahnke, R. M. Kroppenstedt, F. Rainey, and E. Stackebrandt. 1994. Rhodococcus luteus is a later subjective synonym of Rhodococcus fascians. Int. J. Syst. Bacteriol. 44:627-630.

25. Klatte, S., R. M. Kroppenstedt, and F. A. Rainey. 1994. Rhodococcus opacus sp. nov., an unusual nutritionally versatile Rhodococcus species. Syst. Appl. Microbiol. 17:355-360.

26. Kroppenstedt, R. M., E. Stackebrandt, and M. Goodfellow. 1990. Taxonomic revision of the actinomycete genera Actinomadura and Microtetraspora. Syst. Appl. Microbiol. 13:148-160.

27. Krulwich, T. A., and J. L. Pate. 1971. Ultrastructural expression for snapping postfission movements in Arthrobacter crystallopoietes. J. Bacteriol. 105:408412.

28. Larsen, N., G. J. Olsen, B. L. Maidak, M. J. McCaughey, R. Overbeek, T. J. Macke, T. L. Marsh, and C. R. Woese. 1993. The Ribosomal Database Project. Nucleic Acids Res. 21:3021-3023.

29. MacFaddin, J. F. 1985. Media for isolation-cultivation-identification maintenance of medical bacteria, vol. 1, p. 260. Williams and Wilkins, Baltimore.

30. Mesbach, M. U. Premachandran, and W. Whitman. 1989. Precise measurement of the $\mathrm{G}+\mathrm{C}$ content of deoxyribonucleic acid by high-performance liquid chromatography. Int. J. Syst. Bacteriol. 39:159-167.

31. Miller, L., and T. Berger. 1985. Bacterial identification by gas chromatography of whole cell fatty acids. Gas Chromatography Application Note 228 41. Hewlett Packard Co., Palo Alto, Calif.

32. Minnikin, D. E., A. G. O'Donnel, M. Goodfellow, M. Alderson, G. Athalye, A. Schaal, and J. H. Parlett. 1984. An integrated procedure for the extraction of isoprenoid quinones and polar lipids. J. Microbiol. Methods 2:233-241.

33. Peczynska-Czoch, W., and M. Mordarski. 1983. Transformation of xenobiotics, p. 287-336. In M. Goodfellow, M. Mordarski, and S. T. Williams (ed.), The biology of actinomycetes. Academic Press, London.

34. Poon, H. N., and A. W. Day. 1974. "Fimbriae" in the fungus Ustilago violacea. Nature (London) 250:648-649.

35. Poon, H. N., and A. W. Day. 1974. Fungal fimbriae. I. Structure, origin, and synthesis. Can. J. Microbiol. 21:537-546.

36. Rainey, F. A., M. Dorsch, H. W. Morgan, and E. Stackebrandt. 1992. 16S rRNA analysis of Spirochaeta thermophila: its phylogenetic position and implication for the systematics of the order Spirochetales. Syst. Appl. Microbiol., 15:197-202.

37. Stanek, J. L., and G. D. Roberts. 1974. Simplified approach to identification of aerobic actinomycetes by thin-layer chromatography. Appl. Microbiol. 28:226-231.

38. Stoecker, M. A., H. P. Russell, and J. T. Staley. 1994. Rhodococcus zopfii sp. nov., a toxicant-degrading bacterium. Int. J. Syst. Bacteriol. 44:106-110.

39. Sundman, V. 1964. The ability of $\alpha$-conidendrin decomposing Agrobacterium strains to utilize other lignin-related compounds. J. Gen. Microbiol. 36:185201.

40. Tamaoka, J., and K. Komogata. 1984. Determination of DNA base composition by reversed phase high-performance liquid chromatography. FEMS Microbiol. Lett. 25:125-128.

41. Tsukamura, M., I. Yano, K. Takuji, and A. Miyama. 1991. Rhodococcus roseus sp. nov., nom. rev. Int. J. Syst. Bacteriol. 41:385-389

42. Turner, W. B. 1973 . Secondary metabolism with special reference to actinomycetales, p. 209-218. In G. Sykes and F. A. Skinner (ed.), Actinomycetales: characteristics and practical importance. Academic Press, London.

43. Van Loosdrecht, M. C. M., J. Lyklema, W. Norde, and A. J. B. Zehnder. 1987. The role of a bacterial cell wall hydrophobicity in adhesion. Appl. Environ. Microbiol. 53:1893-1897.

44. Winter, B., and W. Zimmermann. 1992. Degradation of halogenated aromatics by actinomycetes, p. 157-203. In H. Sigel and A. Sigel (ed.), Metal ions in biological systems, vol. 28. Marcel Dekker, New York.

45. Yanagawa, R., K. Otsuki, and T. Tokui. 1968. Electron microscopy of fine structure of Corynebacterium renale with special reference to pili. Jpn. J. Vet. Res. 16:31-38.

45a.Zaitsev, G. M., J. S. Uotila, I. V. Tsitko, A. G. Lobanok, and M. S. SalkinojaSalonen. 1995. Utilization of halogenated benzenes, phenols, and benzoates by Rhodococcus opacus GM-14. Appl. Environ. Microbiol. 61:4191-4201.

46. Zuckerkandl, E., and L. Pauling. 1965. Molecules as documents of evolutionary history. J. Theor. Biol. 8:357-366. 